Web Jurnal:

http://ejournal.kemenperin.go.id/jli

\title{
Pengaruh pH dan dosis adsorben dari limbah lumpur aktif industri crumb rubber terhadap kapasitas penyerapan ion $\mathrm{Cd}(\mathrm{II})$ dan $\mathrm{Zn}$ (II)
}

\section{The effect of solution $\mathrm{pH}$ and adsorbent dosage on the adsorption of $\mathrm{Cd}(\mathrm{II})$ and $\mathrm{Zn}(\mathrm{II})$ ions from aquoeous solution by activated sludge of crumb rubber industry}

\author{
1 Balai Riset dan Standardisasi Industri Padang. \\ Jl. Raya LIK No. 23 Ulu Gadut, Padang Indonesia \\ 2 Jurusan kimia, Universitas Negri Padang \\ Jl. Prof Hamka. Air Tawar Padang, Indonesia \\ 3 Program studi kimia, Fakultas Sains dan Teknologi, Universitas Jambi \\ Jl. Raya Jambi-Ma. Bulian Km 15, mendalo Indah. Jambi, Indonesia \\ 4 Politeknik ATI Padang \\ Jl. Bungo Pasang, Tabing, Padang Indonesia \\ 5 Jurusan Teknik Lingkungan, Fakultas Teknik, Universitas Batanghari \\ Jl. Slamet Riyadi, Broni, Jambi, Indonesia \\ * e-mail: rizasalma@gmail.com
}

Salmariza Sy*1, Desy Kurniawati ${ }^{2}$, Intan Lestari ${ }^{3}$, H Harmiwati $^{4}$, Monik Kasman ${ }^{5}$

\begin{tabular}{l}
\hline INFO ARTIKEL \\
\hline Sejarah artikel: \\
Diterima: \\
19 Oktober 2018 \\
Direvisi: \\
12 Desember 2018 \\
Diterbitkan: \\
28 Desember 2018
\end{tabular}

\section{Kata kunci:}

adsorben;

limbah lumpur aktif;

crumb rubber;

LLA-ICR;

dosis

\begin{tabular}{l}
\hline Keywords: \\
adsorbent; \\
activated sludge waste; \\
crumb rubber; \\
LLA-ICR; \\
dosage
\end{tabular}

\begin{abstract}
ABSTRAK
Penelitian dengan sistem batch telah dilakukan untuk mempelajari pengaruh perlakuan pH larutan dan dosis adsorben yang dibuat dari limbah lumpur aktif industri crumb rubber (LLA-ICR) terhadap kapasitas adsorpsi dan efisiensi penyisihan ion $\mathrm{Cd}(\mathrm{II})$ dan $\mathrm{Zn}$ (II) dalam larutan. Pengamatan meliputi variasi $\mathrm{pH}$ larutan pada range 1-7 dan dosis adsorben LLA-ICR 0,1 g - 1,0 g. Karakterisasi adsorben sebelum dan sesudah proses adsorpsi dilakukan dengan menggunakan FTIR, XRF dan SEM-EDX. Hasil penelitian menunjukkan bahwa perlakuan $\mathrm{pH}$ larutan dan dosis adsorben berpengaruh pada kapasitas adsorpsi dan efisiensi penyisihan ion $\mathrm{Cd}(\mathrm{II})$, dan $\mathrm{Zn}$ (II). pH optimum didapatkan pada pH 5. Semakin rendah dosis adsorben, maka semakin tinggi kapasitas adsorpsi namun semakin rendah efisiensi penyisihan ion $\mathrm{Cd}(\mathrm{II})$ dan $\mathrm{Zn}$ (II). Dosis adsorben optimum didapatkan pada $0,1 \mathrm{~g}$, dengan kapasitas adsorpsi dan efisiensi penyisihan ion $\mathrm{Cd}(\mathrm{II})>\mathrm{Zn}$ (II). Kapasitas adsorpsi maksimum untuk ion $\mathrm{Cd}$ (II) dan $\mathrm{Zn}$ (II) berturut-turut $29,8 \mathrm{mg} / \mathrm{g}$ dan $10,3 \mathrm{mg} / \mathrm{g}$. Efisiensi penyisihan maksimum untuk ion Cd(II) dan ion $\mathrm{Zn}(\mathrm{II})$ adalah $95,4 \%$ dan $87,9 \%$.
\end{abstract}




\section{Pendahuluan}

Perkembangan industri harus berorientasi pada industri yang berteknologi ramah lingkungan. Limbah industri yang ada harus memenuhi baku mutu yang telah ditetapkan sehingga limbah harus diolah sebelum dibuang ke lingkungan. Salah satu pengolahan air limbah secara biologis yang paling umum digunakan adalah proses lumpur aktif. Namun, sistem lumpur aktif juga menghasilkan limbah berupa lumpur padat (Limbah Lumpur Aktif / LLA) yang harus dipisahkan dari proses pengolahan limbah.

Pengelolaan dan pembuangan LLA merupakan masalah besar bagi kota dan industri akhir-akhir ini. Contohnya di Eropa, produksi limbah lumpur dari pengolahan air limbah kota diperkirakan 11,5 juta ton pada tahun 2010, yang diperkirakan akan meningkat menjadi 13,0 juta ton pada tahun 2020 (Samolada and Zabaniotou, 2014). Di Kota Padang (Sumatera Barat) LLA menjadi permasalahan bagi 6 industri crumb rubber di mana dalam sebulan masing-masing industri memerlukan biaya tambahan untuk pengiriman \pm 32 ton lumpur LLA ke TPA (Salmariza, 2012).

LLA memiliki komponen utama yang sama dengan lumpur aktif yaitu berupa mikroorganisme, tetapi dalam kondisi yang berbeda di mana kondisi mikroorganisme dalam lumpur aktif masih dalam keadaan hidup, sementara di dalam LLA sudah mati atau kemungkinan ada yang dalam kondisi dormansi karena telah dikeringkan. Pembentukan sel mikroorganisme tersebut tergantung pada komposisi kimia air limbah dan karakteristik khusus dari organisme dalam komunitas biologis (Spellman, 2014). Mikroorganisme seperti khamir, jamur, bakteri, dan alga secara efisien dapat menyerap logam-logam berat dan radionuklida dari lingkungan eksternalnya. Proses ini berlangsung cepat dan terjadi baik pada mikroorganisme hidup maupun mati (Khosravan and Lashkari, 2011).

Selain mengandung banyak mikroba, LLA juga mengandung berbagai kontaminan lainnya yang tergantung sumbernya. Perlakuan dan pembuangan LLA yang tidak tepat akan menyebabkan masalah lingkungan sekunder seperti emisi gas rumah kaca dan kontaminasi pada permukaan tanah. Oleh karena itu, diperlukan pengelolaan LLA yang tepat (Samolada and Zabaniotou, 2014). Selama ini pembuangan yang dilakukan meliputi tempat pembuangan sampah akhir/TPA, penimbun jalan, ke perkebunan, reklamasi hutan dan lahan, dan menjadi bahan bangunan (Ding et al., 2012). Metode pembuangan lumpur secara tradisional seperti aplikasi ke TPA dan lahan pertanian mendapat tekanan besar karena kurangnya lokasi TPA yang tersedia dan tingginya kemungkinan pencemaran lahan pertanian (Smith et al., 2009). Metode lain untuk menambahkan nilai pada limbah padat adalah dengan membakarnya di insinerator, yang menghasilkan output berenergi tinggi dan mengurangi volume pembuangan akhir. Namun, keterbatasan teknik ini adalah menghasilkan dioksin dan produk samping pembakaran yang beracun (GómezPacheco et al., 2012). Pemanfaatan LLA sebagai adsorben merupakan salah satu solusi yang ditawarkan dan mendapat perhatian akhir-akhir ini (Monsalvo et al., 2011).
Sementara itu, industrialisasi yang cepat telah menyebabkan meningkatnya kontaminasi lingkungan oleh logam berat. Pencemaran logam berat oleh industri telah menjadi masalah sanitasi dan lingkungan yang serius di seluruh dunia dalam beberapa tahun terakhir. Logam berat tidak hanya memiliki efek toksik dan berbahaya pada organisme yang hidup di air tetapi juga menumpuk di seluruh rantai makanan dan juga dapat mempengaruhi manusia (Fu and Wang, 2011). Di antara logam-logam berat tersebut adalah seng dan kadmium.

Seng dianggap sebagai elemen penting untuk kehidupan dan bertindak sebagai mikronutrien bila ada dalam jumlah sedikit. Hal ini penting untuk fungsi fisiologis jaringan hidup dan mengatur banyak proses biokimia. Namun, peningkatan kadar seng dalam tubuh menyebabkan masalah kesehatan. Gejala toksisitas seng termasuk sifat lekas marah atau mudah tersinggung, kram perut, kekakuan otot, kehilangan nafsu makan, mual, dan muntah. Logam tersebut juga dapat terakumulasi dalam flora dan fauna yang menciptakan masalah ekologis (Fu and Wang, 2011).

Sedangkan kadmium adalah elemen non esensial dan merupakan salah satu ion logam yang sangat beracun bagi organisme meskipun dalam jumlah yang sedikit, yang dicirikan dengan kestabilannya yang tinggi dan sifat toksitnya. Ia tidak dapat didegradasi di alam sehingga sekali lingkungan terpapar oleh kadmium, maka ia akan tetap ada dalam sirkulasi dan membutuhkan waktu yang sangat lama untuk memulihkannya (Khosravan and Lashkari, 2011).

Kadmium berdampak buruk pada beberapa enzim penting yang menyebabkan penyakit tulang dan kerusakan ginjal. Berbagai sindrom, hipertensi fungsi ginjal, cedera hati, kerusakan paru-paru, dan efek teratogenik dapat terjadi akibat toksisitas kadmium (Ihsanullah et al., 2015). Penyakit Itai-Itai, yang disebabkan oleh keracunan kadmium dan yang menyebabkan pelunakan tulang dan kegagalan ginjal penduduk di daerah sungai Jinzu di prefektur Toyama, adalah salah satu masalah lingkungan yang paling parah di Jepang (Siswoyo et al., 2014; Sy et al., 2016).

Banyak metoda yang telah digunakan untuk penanggulangan pencemaran logam berat di perairan di antaranya presipitasi, elektrodialisis, pertukaran ion, reverse osmosis, filtrasi membran, coagulation, ektraksi dan adsorpi dengan karbon aktif dan resin penukar ion, yang memerlukan biaya yang sangat mahal dan tidak efektif. Di samping itu, pemanfaatan LLA sebagai adsorben juga telah banyak dilaporkan. Beberapa di antaranya adalah dari clarifield sludge dari industri baja (Bhattacharya et al., 2006), limbah lumpur pengolahan air limbah kota (Yang et al., 2010), pabrik tekstil (Hunsom and Autthanit, 2013), pabrik kosmetik (Monsalvo et al., 2011), industri proses produksi plastik dan pupuk (Velghe et al., 2012), pabrik susu (Khosravan and Lashkari, 2011) pabrik sawit, (Zaini et al., 2013), dan pengolahan air minum (Abo-El-Enein et al., 2017).

Penelitian pemanfaatan LLA dari instalasi pengolahan air limbah (IPAL) industri crumb rubber (LLA-ICR) sebagai adsorben belum banyak dipublikasikan. Beberapa yang telah dilaporkan adalah untuk menyerap logam Cr (Salmariza, 2012; Salmariza et al., 2014) untuk menyerap logam Cd (Sy et al., 2016) 
dan untuk menyerap logam Zn (Sy et al., 2018). Pada penelitian ini telah dilakukan pemanfaatan LLA-ICR sebagai adsorben logam berat ion $\mathrm{Cd}(\mathrm{II})$ dan $\mathrm{Zn}$ (II) dengan melihat pengaruh perlakuan $\mathrm{pH}$ larutan dan dosis. Pengamatan kapasitas penyerapan dan efisiensi penyerapan ion $\mathrm{Cd}(\mathrm{II})$ dan $\mathrm{Zn}(\mathrm{II})$ dipelajari dengan menggunakan sistim batch.

\section{Metode}

Bahan yang digunakan dalam penelitian ini adalah limbah lumpur aktif (LLA) proses activated sludge dari sistem Instalasi Pengolahan Air Limbah (IPAL) pada tangki pengeringan di industri crumb rubber PT. Kilang Lima Gunung, asam nitrat $\left(\mathrm{HNO}_{3}\right) 0,01 \mathrm{M}, \mathrm{HCl}$, natrium hidroksida $(\mathrm{NaOH})$, kadmium nitrat $\mathrm{Cd}\left(\mathrm{NO}_{3}\right)_{2}$, seng nitrat $\mathrm{Zn}\left(\mathrm{NO}_{3}\right)$, dan Double Destilled Water. Semua bahan kimia yang digunakan dengan tingkat kemurnian tinggi (p.a) keluaran Merck Germany.

Peralatan yang digunakan untuk persiapan dan pengerjaan sampel adalah peralatan gelas (pyrex), neraca analitis, oven (Memmert UNB 300), alat pirolisis, muffle furnace Thermoline-6000, desikator, ayakan test siever merek Retsch 5657 Haun W. Germany No. 40 mesh dan No. 60 mesh, shaker merek Adjustable Reciprocating Orbital Shaker (AROS)160TM, pH meter, Atomic Absorption Spectrophotometry (AAS) merek AAS GBC 932 AA. Untuk karakterisasi sampel sebelum dan sesudah proses adsorpsi digunakan XRF (X-ray fluorescence spectrometer) merek PANalytical ELMilon3, FTIR (Fourier Transform Infrared Spectrometer) merek Perkin Elmer, SEM-EDX (Scanning Electron Microscopy-Energy Dispersive X-ray Spectroscopy) model S-3400N, dan kertas saring Whatman 42.

\subsection{Metode preparasi sampel}

Limbah lumpur akrif industri crumb rubber (LLAICR) dari bak klarifier dikumpulkan dan dikeringkan. Sampel lumpur dikeringkan selama tiga hari dengan sinar matahari dan kemudian dikeringkan lagi dalam oven pada suhu $70^{\circ} \mathrm{C}$ selama kurang lebih 5 jam. Kemudian digiling dan diayak dengan ayakan nomor 40 mesh dan tertahan pada nomor 60 mesh (ukuran partikel $420 \mu \mathrm{m}$ ) dengan menggunakan alat siever. Sampel dikemas dan disimpan dalam desikator dan siap untuk digunakan.

\subsection{Percobaan adsorpsi secara batch}

\subsubsection{Pengaruh pH larutan pada penyerapan ion Cd(II), dan Zn(II)}

Pada sebanyak $20 \mathrm{~mL}$ larutan ion $\mathrm{Cd}(\mathrm{II})$ dan $\mathrm{Zn}$ (II) dengan konsentrasi masing-masing $10 \mathrm{mg} / \mathrm{L}$, yang telah diatur $\mathrm{pH}$ larutannya menjadi $\mathrm{pH} 1,2,3,4,5,6$, dan 7 dengan menambahkan $\mathrm{NaOH} 0,01 \mathrm{M}$, dimasukkan ke dalam 7 buah erlenmeyer $50 \mathrm{~mL}$, masing-masing ditambahkan adsorben LLA-ICR sebanyak 0,5 gram, kemudian diaduk dengan shaker dengan kecepatan 180 rpm selama 30 menit. Kemudian larutan dipisahkan dengan cara menyaring filtratnya dengan kertas saring Whatman 42 dan dianalisis dengan AAS.

\subsubsection{Pengaruh dosis adsorben pada penyerapan Cd(II), dan Zn(II)}

Masing-masing sebanyak $20 \mathrm{~mL}$ larutan Cd(II) dan $\mathrm{Zn}(\mathrm{II})$, dengan konsentrasi optimum, yang telah diatur $\mathrm{pH}$ larutannya menjadi $\mathrm{pH}$ optimum dengan menambahkan $\mathrm{NaOH}$ 0,01 M. Kemudian dimasukkan ke dalam 10 buah erlenmeyer $50 \mathrm{~mL}$ dan ditambahkan adsorben LLA-ICR sebanyak 0,1, 0,2, 0,3, 0,4, 0,5, 0,6, $0,7,0,8,0,9$ dan 1 gram. Kemudian diaduk dengan shaker pada kecepatan $180 \mathrm{rpm}$ selama waktu optimum yang telah didapatkan. Kemudian larutan dipisahkan dengan cara menyaring filtratnya dengan kertas saring Whatman 42 dan dianalisis dengan AAS.

\subsection{Analisis data}

\subsubsection{Perhitungan kapasitas penyerapan}

Konsentrasi masing-masing logam saat setimbang dan konsentrasi mula-mula ditentukan secara Spektrofotometri Serapan Atom. Banyaknya ion logam $\mathrm{Cd}(\mathrm{II})$ dan $\mathrm{Zn}(\mathrm{II})$ yang teradsorpsi (mg) per gram adsorben ditentukan dengan menggunakan persamaan (1).

$$
\mathrm{Qe}=\frac{(\mathrm{Co}-\mathrm{Ce}) \times \mathrm{V}}{W a}
$$

Dimana Qe $=$ Kapasitas adsorpsi pada saat kesetimbangan $(\mathrm{mg} / \mathrm{g})$, Co $=$ konsentrasi larutan ion logam awal $(\mathrm{mg} / \mathrm{L}), \mathrm{Ce}=$ konsentrasi larutan ion logam pada saat kesetimbangan $(\mathrm{mg} / \mathrm{L}), \quad \mathrm{Wa}=$ berat adsorben (gram) dan $\mathrm{V}=$ Volume larutan ion logam (L).

\subsubsection{Analisis statistik}

Semua data dianalisis secara statistik dengan menggunakan SPSS yang menggunakan analisis varians (ANOVA) dan uji lanjut Duncan's New Multiple Range Test (DNMRT) pada tingkat signifikansi 5\%. Adsorben LLA-ICR sebelum dan sesudah proses adsorpsi dikarakterisasi dengan menggunakan FTIR, XRF dan SEM-EDX.

\section{Hasil dan pembahasan}

\subsection{Pengaruh pH terhadap kapasitas adsorpsi Cd(II)} dan $\mathrm{Zn}$ (II)

Secara umum, kemampuan adsorpsi ion logam berat oleh adsorben dari dalam larutan akan dipengaruhi oleh pH larutan. Keasaman medium mempengaruhi kompetisi ion hidrogen dan ion logam pada situs aktif permukaan adsorben (Sharma and Lee, 2014). Kapasitas adsorpsi dari adsorben LLA-ICR dianalisis pada kisaran $\mathrm{pH} 1$ sampai 7. Pengaruh $\mathrm{pH}$ terhadap adsorpsi ion $\mathrm{Cd}(\mathrm{II})$ dan Zn(II) ditunjukkan pada Gambar 1.

Dari Gambar 1 terlihat bahwa kapasitas adsorpsi ion $\mathrm{Cd}(\mathrm{II})$ meningkat dengan kenaikan $\mathrm{pH}$ sampai dengan penyerapan maksimum pada $\mathrm{pH} 5$, kemudian menurun dengan meningkatnya $\mathrm{pH}$ dari $\mathrm{pH} 5$ sampai $\mathrm{pH}$ 7. Hal itu dapat dilihat dari peningkatan kapasitas adsorpsi (Qe) dari $0,222 \mathrm{mg} / \mathrm{g}$ sampai $0,379 \mathrm{mg} / \mathrm{g}$ dan menurun 
menjadi 0,345 mg/g. Sama halnya dengan Cd(II), pada $\mathrm{Zn}$ (II) juga terjadi peningkatan kapasitas adsorpsi dari $0,155 \mathrm{mg} / \mathrm{g}$ sampai $0,332 \mathrm{mg} / \mathrm{g}$ pada $\mathrm{pH} 1-5$, kemudian menurun menjadi $0,029 \mathrm{mg} / \mathrm{g}$ pada $\mathrm{pH}$ 7. Hal ini dapat dijelaskan bahwa pada $\mathrm{pH}$ rendah protonasi terjadi pada permukaan adsorben LLA-ICR sehingga dapat memblokir situs aktif yang tersedia untuk adsorpsi ion logam positif, sementara dengan meningkatnya $\mathrm{pH}$, protonasi akan menurun dan muatan negatif pada permukaan adsorben akan lebih dieksploitasi menghasilkan daya tarik elektrostik terhadap ion logam positif dalam larutan (Abo-El-Enein et al., 2017).

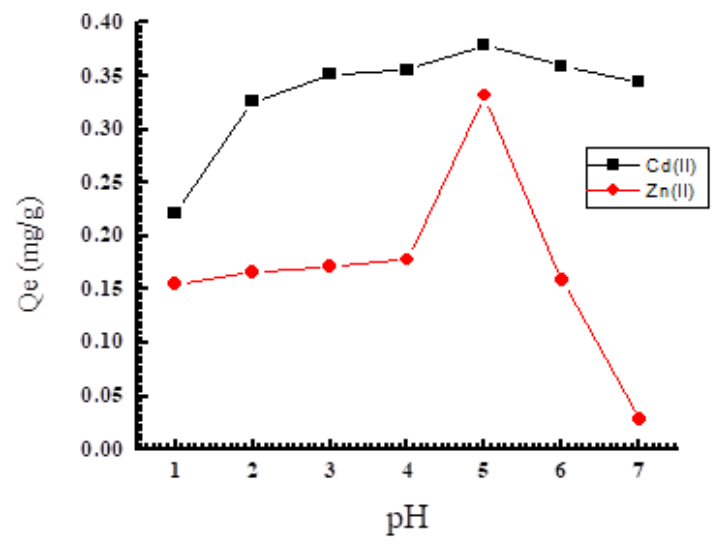

Gambar 1. Pengaruh $\mathrm{pH}$ larutan terhadap kapasitas adsorpsi ion $\mathrm{Cd}(\mathrm{II})$ dan $\mathrm{Zn}$ (II) dengan adsorben LLAICR. (Konsentrasi awal = $10 \mathrm{mg} / \mathrm{L}$, vol larutan $20 \mathrm{~mL}$, ukuran partikel $420 \mu \mathrm{m}$, massa $0,5 \mathrm{~g}$, waktu kontak 30 menit, kecepatan pengadukan $180 \mathrm{rpm}$

Selanjutnya pada nilai $\mathrm{pH}$ yang lebih rendah (1-3), penyerapan juga rendah, karena adsorpsi ion $\mathrm{Cd}(\mathrm{II})$ dihambat. Kemungkinan hal ini terjadi sebagai hasil persaingan antara ion hidrogen dan ion logam pada sisi aktif penyerapan. Dengan kelebihan ion hidrogen dapat membatasi pendekatan kation logam (Farhan et al., 2013). Peningkatan efisiensi penyisihan secara linear dilaporkan juga telah terjadi dari $\mathrm{pH}$ 1-6 pada adsorpsi Zn(II) (Gupta et al., 2010). Hal ini mungkin disebabkan karena dengan meningkatnya $\mathrm{pH}$ larutan, maka permukaan adsorben menjadi negatif sehingga terjadi peningkatan adsorpsi (Yang et al., 2010).

Untuk menguji kebenaran perbedaan nilai $\mathrm{pH}$ yang didapat signifikan dengan kapasitas adsorpsi dilakukan analisis secara statistik dengan menggunakan software SPSS dengan menggunakan uji Anova (analysis of variance) dan uji lanjut menggunakan uji DNMRT pada tingkat kepercayaan 5\%.

Dari uji lanjut Duncan didapatkan $\mathrm{pH}$ optimum untuk penyerapan ion $\mathrm{Cd}(\mathrm{II})$ dan $\mathrm{Zn}$ (II) diperoleh pada $\mathrm{pH} 5$ karena memberikan kapasitas adsorpsi ion $\mathrm{Cd}$ (II) dan $\mathrm{Zn}$ (II) tertinggi yang berbeda nyata dengan $\mathrm{pH}$ lainya dan akan digunakan sebagai $\mathrm{pH}$ perlakuan dalam perlakuan selanjutnya. Hal ini sama dengan penelitian adsorbsi Cd(II) menggunakan daun ficus carcia, zeolit, dan lumpur, yang juga mendapatkan $\mathrm{pH}$ optimum pada pH 5 (Farhan et al., 2013; Gutiérrez-Segura et al., 2012; Naiya et al., 2008; Siswoyo et al., 2014). Begitu juga penelitian yang mempelajari adsorpsi ion $\mathrm{Zn}$ (II) dengan lumpur, daun kacang kedelei, dan biji durian yang telah dilaporkan dan diperoleh $\mathrm{pH}$ optimum pada $\mathrm{pH} 5$ (Bhattacharya et al., 2006; Harmiwati et al., 2017; Lestari et al., 2016; Velghe et al., 2012).

Pengaruh $\mathrm{pH}$ juga dapat dijelaskan dalam hal muatan permukaan dari adsorben yang dikenal dengan zero point of charge yang disimbolkan dengan $\mathrm{pH}_{\mathrm{zpc}}$ atau $\mathrm{pH}_{\mathrm{pzc}}$. Permukaan adsorben positif pada $\mathrm{pH}<\mathrm{pH}_{\mathrm{pzc}}$, netral pada $\mathrm{pH}=\mathrm{pH}_{\mathrm{pzc}}$ dan negatif pada $\mathrm{pH}>\mathrm{pH}_{\mathrm{pzc}} \quad$ (Rao and Kashifuddin, 2016). $\mathrm{pH}_{\mathrm{pzc}}$ dari sludge didapatkan 4,1 sampai 5,4 (Hadi et al., 2015), sehingga adsorpsi Cd(II) dan $\mathrm{Zn}(\mathrm{II})$ paling rendah pada $\mathrm{pH}$ di bawah $\mathrm{pH} 4$ dan meningkat dengan kenaikan $\mathrm{pH}$ sampai $\mathrm{pH} 5$, karena elektrostatik daya tarik antara ion $\mathrm{Cd}(\mathrm{II})$ dan $\mathrm{Zn}$ (II) bermuatan positif dan permukaan adsorben bermuatan negatif.

\subsection{Pengaruh dosis adsorben terhadap kapasitas adsorpsi Cd(II) dan $\mathrm{Zn}$ (II)}

Dosis adsorben juga mempengaruhi efisiensi penyisihan $(\% \mathrm{R})$ dan kapasitas adsorpsi (Qe) ion logam, dimana efisiensi penyisihan berbanding terbalik dengan kapasitas adsorpsi. Efisiensi penyisihan meningkat sejalan dengan meningkatnya dosis adsorben. Dengan bertambahnya adsorben, maka luas permukaan juga akan bertambah, sehingga sisi aktif pada adsorben juga bertambah banyak untuk mengikat dan menjerap adsorbat yang menyebabkan efisiensi penyisihan menjadi meningkat. Sebaliknya, kapasitas adsorpsi meningkat sejalan dengan penurunan dosis adsorben karena kapasitas adsorpsi dihitung sebagai jumlah ion logam yang teradsorpsi per gram adsorben. Semakin banyak dosis adsorben, maka kapasitas adsorpsi semakin menurun. Peningkatan dosis adsorben menyebabkan proporsi jumlah ion logam berkurang dalam larutan yang berhubungan dengan jumlah sisi aktif pada adsorben, yang dapat menyebabkan perubahan kesetimbangan adsorpsi. Oleh karena itu, bila dosis adsorben meningkat, situs aktif di permukaan adsorben menjadi tidak jenuh dan menyebabkan kapasitas adsorpsi menurun (Phuengprasop et al., 2011).

Sementara itu, untuk aplikasi penggunaan adsorben perlu dipertimbangkan dari sisi ekonomis sehingga penggunaan dosis dihitung dari dosis paling minimal namun dapat menghasilkan kemampuan penyerapan yang tertinggi. Oleh karena itu semakin sedikit berat adsorben, maka semakin tinggi kapasitas adsorpsi. Pengaruh dosis adsorben pada adsorpsi ion $\mathrm{Cd}(\mathrm{II})$ dan $\mathrm{Zn}(\mathrm{II})$ dipelajari dengan menggunakan variasi berat pada kisaran 0,1 g - 1,0 g (Gambar 2.). Hasil penelitian menunjukkan bahwa efisiensi penyisihan (\%R) dan kapasitas adsorpsi qe sangat bergantung pada jumlah adsorben yang ditambahkan. Dari Gambar 2 dapat dilihat bahwa adsorben LLA-ICR dapat menyerap sampai 95,4\% ion $\mathrm{Cd}(\mathrm{II})$ dan $87,9 \%$ ion $\mathrm{Zn}(\mathrm{II})$. Berat adsorben LLA-ICR optimum untuk adsorpsi ion Cd(II) dan Zn(II) ditemukan pada dosis 0,1 gram dengan kapasitas adsorpsi maksimum didapatkan $29,819 \mathrm{mg} / \mathrm{g}$ untuk adsorpsi ion Cd(II) dan 10,267 mg/g untuk adsorbsi ion $\mathrm{Zn}(\mathrm{II})$. Terlihat bahwa kapasitas adsorpsi Cd(II) lebih tinggi dari $\mathrm{Zn}(\mathrm{II})$. 


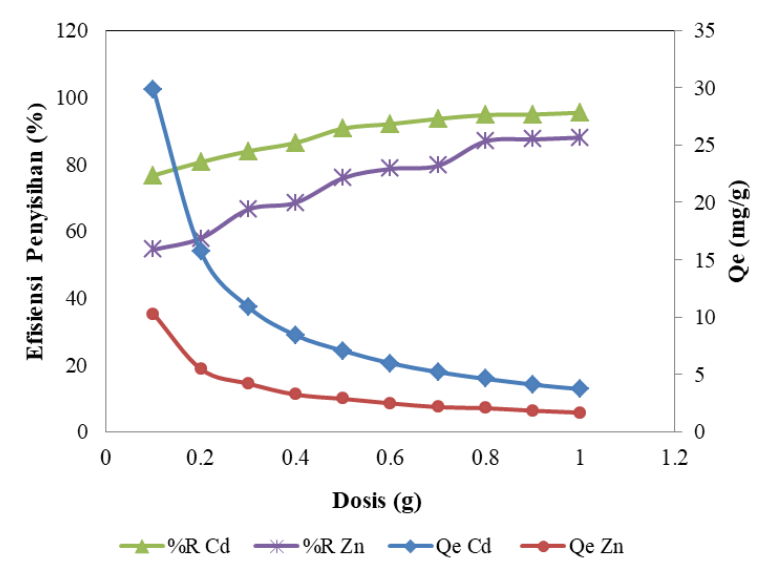

Gambar 2. Pengaruh dosis adsorben LLA-ICR terhadap efisiensi penyisihan dan kapasitas adsorpsi ion $\mathrm{Cd}(\mathrm{II})$ dan $\mathrm{Zn}(\mathrm{II})$. (Konsentrasi awal $=10 \mathrm{mg} / \mathrm{L}$, vol larutan 20 mL, ukuran partikel $420 \mu \mathrm{m}$, massa $0,5 \mathrm{~g}$, waktu kontak 30 menit, kecepatan pengadukan $180 \mathrm{rpm}$

Penelitian lain yang telah dilaporkan juga mendapatkan efisiensi penyerapan ion Cd(II) 90\%-99\% dengan adsorben lumpur pengolahan air minum (AboEl-Enein et al., 2017) dan efisiensi penyerapam $\mathrm{Zn}(\mathrm{II})$ dengan adsorben lumpur indusri baja 94,6\%-98,7\% (Bhattacharya et al., 2006). Begitu juga dengan kapasitas penyerapan $\mathrm{Cd}(\mathrm{II})$ yang telah dilaporkan diantaranya $20,97 \mathrm{mg} / \mathrm{g}$ dengan lumpur pengolahan hasil laut (Khosravan and Lashkari, 2011), 14,7 mg/g dan 5,3-9,2 $\mathrm{mg} / \mathrm{g}$ dengan lumpur IPAL komunal (Phuengprasop et al., 2011; Siswoyo et al., 2014). Sedangkan kapasitas penyerapan $\mathrm{Zn}$ (II) $15,53 \mathrm{mg} / \mathrm{g}$ (Bhattacharya et al., 2006) dengan lumpur pabrik baja, dan $5,5 \mathrm{mg} / \mathrm{g}$ dengan lumpur Industri proses produksi plastik dan pupuk (Velghe et al., 2012).

Kapasitas adsorpsi Cd(II) terlihat lebih tinggi jika dibandingkan dengan kapasitas adsorpsi Zn(II). Tingginya kapasitas adsorpsi Cd(II) dibanding Zn(II), dapat dikaitkan dengan indeks kovalens ion logam (Freitas et al., 2008). Potensi ion logam menjadi kompleks ligan tergantung pada kekuatan polarisasinya, yaitu, berdasarkan muatan, rasio radius kation. Akumulasi daya polarisasi tinggi memiliki densitas muatan positif yang tinggi dan digambarkan sebagai asam Lewis yang kuat. Energi orbital yang kosong dari ion logam diambil sebagai ukuran kemampuannya untuk menerima elektron dan dengan demikian membentuk ikatan kovalen. Energi orbit berhubungan dengan elektronegativitas (Xm), yang dapat didefinisikan sebagai ukuran daya tarik atom suatu elemen untuk pasangan elektron bersama dalam ikatan kovalen (Brady and Tobin, 1995).

Indeks perilaku ion logam kelas B yang dikenal sebagai indeks kovalen, dihitung dengan menggunakan $\mathrm{Xm} * \mathrm{r}$, di mana $\mathrm{Xm}$ adalah elektronegativitas dan $\mathrm{r}$ adalah jari-jari ionik. $\mathrm{Sr}^{2+}$ adalah logam kelas $\mathrm{A}$, sedangkan $\mathrm{Mn}^{2+}, \mathrm{Zn}^{2+}, \mathrm{Cd}^{2+}, \mathrm{Cu}^{2+}$, dan $\mathrm{Pb}^{2+}$ adalah logam batas. Nilai indeks kovalen logam ini meningkat sesuai urutan: $\mathrm{Sr}^{2+}<\mathrm{Mn}^{2+}<\mathrm{Zn}^{2+}<\mathrm{Cd}^{2+}<\mathrm{Cu}^{2+}<\mathrm{Pb}{ }^{2+}$. Secara umum, semakin besar nilai indeks kovalen ion logam, maka semakin besar tingkat karakter kelas B, dan akibatnya akan berpotensi untuk membentuk ikatan kovalen dengan ligan (Brady and Tobin, 1995).

Selain itu, tingginya kapasitas adsorpsi Cd(II) dibanding Zn(II), juga dapat dikaitkan hasil analisis XRF dan EDX (Tabel 1 dan 2) dengan lebih tingginya persentase kadar $\mathrm{Cd}(\mathrm{II})$ setelah proses adsorpsi dibanding dengan persentase kadar $\mathrm{Zn}$ (II) sesudah proses adsorpsi. Hal ini juga didukung dengan spektra FTIR yang memperlihatkan penurunan intensitas transmitan Cd(II) setelah proses adsorpsi lebih tinggi dibanding Zn(II) (Gambar 3 dan 4).

Beberapa penelitian yang mendapatkan kapasitas adsorpsi dengan urutan $\mathrm{Cd}(\mathrm{II})>\mathrm{Zn}$ (II) antara lain; Adsorpsi menggunakan polimer yang dibuat dari lumpur yang mendapatkan $\mathrm{Pb}$ (II) $>\mathrm{Cd}$ (II) $>\mathrm{Zn}$ (II) (Liu et al., 2015), dari lumpur anaerobik yang mendapatkan $\mathrm{Cu}(\mathrm{II})>\mathrm{Cd}(\mathrm{II})>\mathrm{Zn}$ (II) $>\mathrm{Ni}$ (II) (Artola et al., 2000), dari batang bambu yang mendapatkan $\mathrm{Cd}>\mathrm{Hg}>\mathrm{Zn}$ (González and Pliego-Cuervo, 2014), dari chitosan dan resin yang mendapatkan $\mathrm{Hg}(\mathrm{II})>\mathrm{Cd}(\mathrm{II})>\mathrm{Zn}$ (II) (Monier and AbdelLatif, 2012) dan dari silica gel yang mendapatkan $\mathrm{Cu}(\mathrm{II})>\mathrm{Cd}(\mathrm{II})>\mathrm{Zn}$ (II) $>\mathrm{Ni}$ (II) (Li et al., 2014).

\subsection{Karakterisasi adsorben LLA-ICR sebelum dan sesudah proses adsorpsi ion $\mathrm{Cd}$ (II) dan $\mathrm{Zn}$ (II)}

Karakterisasi Adsorben LLA-ICR sebelum dan sesudah proses adsorpsi ion $\mathrm{Cd}(\mathrm{II})$ dan $\mathrm{Zn}$ (II) dapat dilihat pada Gambar 3 dan 4 (dengan FTIR), Tabel 1 dan 2 (dengan XRF) dan Gambar 5 (dengan SEM-EDX).

Karakterisasi menggunakan spektrofotometri FTIR menunjukkan bahwa adsorben memiliki beberapa gugus fungsi yang berperan dalam proses adsorpsi (Gambar 3 dan 4). Dari Gambar 3 dan 4 terlihat adsorben LLA-ICR sebelum dan sesudah proses adsorpsi ion $\mathrm{Cd}(\mathrm{II})$ dan $\mathrm{Zn}$ (II) mempunyai tiga puncak gelombang utama pada bilangan gelombang yang sama, dengan intensitas yang berbeda. Pita serapan kuat pada antara $3000 \mathrm{~cm}^{-1}-3500$ $\mathrm{cm}^{-1}$ dapat dikaitkan dengan mode vibrasi peregangan dari ikatan $\mathrm{O}-\mathrm{H}$ dalam permukaan gugus hidroksil atau molekul air teradsorpsi. Puncak ke dua pada daerah 1633 $\mathrm{cm}^{-1}$ dapat dikaitkan dengan mode vibrasi peregangan dari ikatan gugus fungsional karboksil $\mathrm{C}=\mathrm{O}$ atau ikatan group fungsional alkena $\mathrm{C}=\mathrm{C}$. Selain itu, vibrasi lentur dari $\mathrm{H}_{2} \mathrm{O}$ yang teradsorpsi pada permukaan adsorben, juga dapat berkontribusi pada proses penyerapan (Cheng et al., 2016).

Adanya puncak ketiga pada daerah $1030 \mathrm{~cm}^{-1}$ menunjukkan adanya peregangan $\mathrm{Si}-\mathrm{O}-\mathrm{Si}$ atau $\mathrm{Si}-\mathrm{O}-\mathrm{C}$. Selain itu juga terlihat puncak adanya kecil pada 2223 $\mathrm{cm}^{-1}$ yang menunjukkan peregangan ikatan $\mathrm{C} \equiv \mathrm{N}$. Puncak kecil lainnya ditemukan pada $675 \mathrm{~cm}^{-1}-695 \mathrm{~cm}^{-}$ 1 yang dikaitkan dengan ikatan $\mathrm{Si}-\mathrm{O}$ dalam kelompok $\mathrm{SiO}_{4}$. Hasil yang hampir sama juga dilaporkan pada limbah lumpur IPAL di China (Cheng et al., 2016), yang mendapatkan puncak pada daerah $3441 \mathrm{~cm}^{-1}$ dapat dikaitkan dengan mode peregangan ikatan $\mathrm{OH}$ pada gugus hidroksil permukaan atau molekul air. Puncak pada $1618 \mathrm{~cm}^{-1}$ dapat dikaitkan dengan mode vibrasi peregangan ikatan $\mathrm{C}=\mathrm{O}$ atau ikatan $\mathrm{C}=\mathrm{C}$. Puncak yang paling tajam pada $1,033 \mathrm{~cm}^{-1}$, menunjukkan adanya ikatan Si-O-Si atau Si-O-C. Puncak kecil yang 
ditemukan pada $2225 \mathrm{~cm}^{-1}$ sesuai dengan mode vibrasi peregangan $\mathrm{C} \equiv \mathrm{N}$ atau ikatan $\mathrm{C} \equiv \mathrm{N}$. Puncak kecil lainnya ditemukan pada $694 \mathrm{~cm}^{-1}$ dan dikaitkan dengan mode vibrasi simetris ikatan $\mathrm{Si}-\mathrm{O}$ dalam kelompok $\mathrm{SiO}_{4}$.

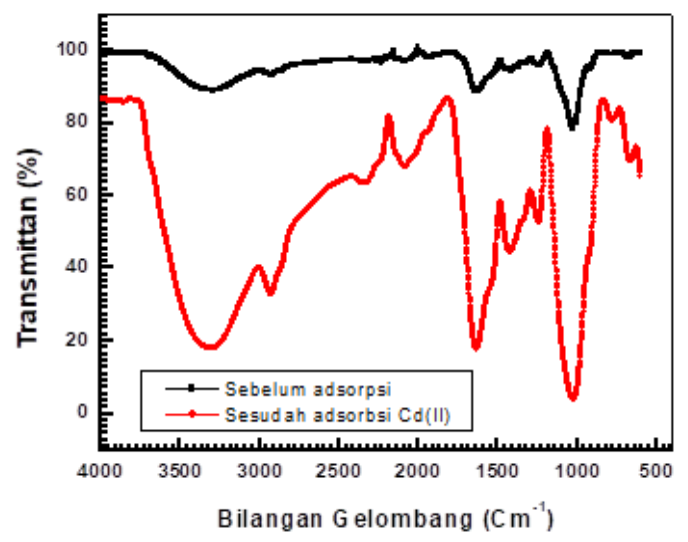

Gambar 3. Spektrum FTIR adsorben LLA-ICR sebelum dan sesudah proses adsorpsi Cd(II)

Hasil analisis FTIR lumpur IPAL komunal juga mendapatkan puncak pada $3430 \mathrm{~cm}^{-1}$ yang mengidentikkan adanya kelompok gugus fungsional hidroksil $(-\mathrm{OH})$. Pada $1640 \mathrm{~cm}^{-1}$ ditemukan $\mathrm{NH}_{2}-\mathrm{C}=\mathrm{O}$ untuk kelompok gugus fungsional akrilamida dan pada $1020 \mathrm{~cm}^{-1}$ ditemukan kelompok gugus fungsional karboksil C-O (Wu et al., 2013). Begitu juga pada lumpur pengolahan air minum yang mendapatkan $-\mathrm{OH}$ stretching pada puncak antara 3385 dan $3417 \mathrm{~cm}^{-1}$ yang mengidentikkan adanya kelompok gugus fungsional hidroksil (Zaini et al., 2013).

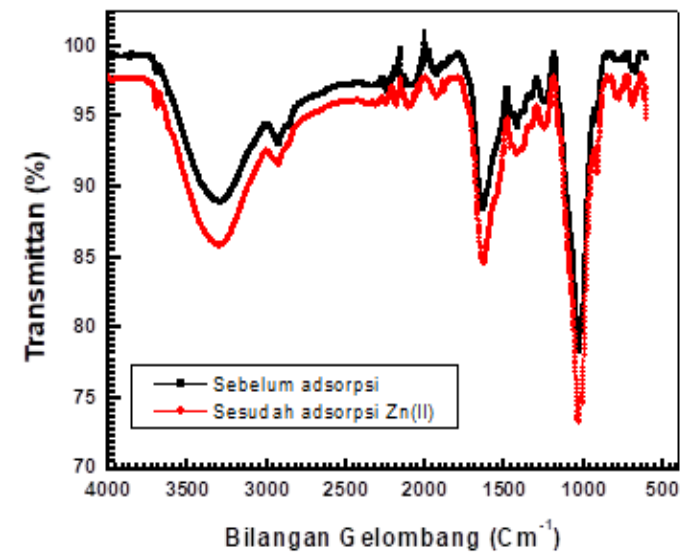

Gambar 4. Spektrum FTIR adsorben LLA-ICR sebelum dan sesudah proses adsorpsi $\mathrm{Zn}(\mathrm{II})$.

Puncak gelombang utama pada semua tipe adsorben tetap terlihat, baik sebelum maupun sesudah proses adsorpsi $\mathrm{Cd}(\mathrm{II})$ dan $\mathrm{Zn}(\mathrm{II})$, namun dengan intensitas yang berbeda dan cenderung menurun. Terlihat bahwa terjadi penurunan intensitas/persentase trasmitan spektra FTIR setelah proses adsorpsi Cd(II) dan Zn(II) di mana penurunan sesudah proses adsorpsi $\mathrm{Cd}$ (II) terlihat lebih tinggi dibanding sesudah proses adsorpsi $\mathrm{Zn}(\mathrm{II})$.

Tabel 1

Analisis XRF kadar elemen dan oksida adsorben LLA-ICR sebelum dan sesudah proses adsorpsi ion Cd(II) dan Zn(II)

Kadar Elemen $(\%)$

\begin{tabular}{llll}
\hline Elemen & $\begin{array}{l}\text { Sebelum } \\
\text { Adsorpsi }\end{array}$ & $\begin{array}{l}\text { Sesudah } \\
\text { Adsorpsi Cd(II) }\end{array}$ & $\begin{array}{l}\text { Sesudah } \\
\text { Adsorpsi Zn(II) }\end{array}$ \\
\hline $\mathrm{Al}$ & 13,628 & 12,827 & 11,952 \\
$\mathrm{Si}$ & 55,786 & 27,402 & 28,511 \\
$\mathrm{~K}$ & 1,523 & 0,847 & 0,912 \\
$\mathrm{Ca}$ & 20,389 & 12,446 & 16,884 \\
$\mathrm{Fe}$ & 6,223 & 3,962 & 6,071 \\
$\mathrm{Zn}$ & 0,114 & 0,069 & 6,363 \\
$\mathrm{Cd}$ & 0 & 19,132 & 0 \\
\hline
\end{tabular}

Dari Tabel 1. dapat dilihat bahwa adsorben LLA-ICR mengandung elemen kimia Al, Si, K. Ca, Fe dan Zn baik dalam bentuk unsur tunggal maupun dalam bentuk oksida. LLA-ICR mengandung Si, Ca dan Al yang lebih tinggi dibandingkan dengan unsur K, Fe dan Zn. Kadar silika sebelum proses adsorpsi mencapai 55,786\%, kalsium 20,389\%, aluminium 13,628\%, sedangkan dalam bentuk oksidanya, kadar silikon dioksida mencapai $63,203 \%$, alumina oksida $16,076 \%$, kalsium oksida $11,914 \%$, di mana nantinya akan banyak berperan sebagai sisi aktif adsorben untuk menyerap ion Cd(II) dan $\mathrm{Zn}(\mathrm{II})$. Hal ini dapat dilihat dari penurunan kadar Si, $\mathrm{Ca}$ dan $\mathrm{Al}$ setelah proses adsorpsi $\mathrm{Cd}(\mathrm{II})$ berturut-turut menjadi $27,402 \%, 12,446 \%$ dan $12,827 \%$ dan $\mathrm{Zn}(\mathrm{II})$ berturut-turut menjadi $28,511 \%, 16,884 \%$ dan 11,952 .

\begin{tabular}{llll}
\multicolumn{2}{l}{ Kadar Oksida $(\%)$} \\
\hline Oksida & $\begin{array}{l}\text { Sebelum } \\
\text { Adsorpsi }\end{array}$ & $\begin{array}{l}\text { Sesudah } \\
\text { Adsorpsi Cd(II) }\end{array}$ & $\begin{array}{l}\text { Sesudah } \\
\text { Adsorpsi Zn(II) }\end{array}$ \\
\hline $\mathrm{Al}_{2} \mathrm{O}_{3}$ & 16,076 & 14,262 & 15,778 \\
$\mathrm{SiO}_{2}$ & 63,203 & 35,677 & 36,68 \\
$\mathrm{~K}_{2} \mathrm{O}$ & 0,757 & 0,49 & 0,561 \\
$\mathrm{CaO}$ & 18,411 & 8,074 & 11,914 \\
$\mathrm{Fe}_{2} \mathrm{O}_{3}$ & 3,168 & 2,439 & 4,403 \\
$\mathrm{ZnO}$ & 0,048 & 0,036 & 3,286 \\
$\mathrm{CdO}$ & 0 & 10,971 & 0
\end{tabular}

Begitu juga dengan kadar oksidanya turun berturut-turut menjadi 35,677\%, 8,074\% dan 14,262\% setelah proses adsorpsi Cd(II), serta 36,68\%, 11,914\% dan 15,778\% setelah proses adsorpsi $\mathrm{Zn}(\mathrm{II})$.

Peran unsur dan oksida $\mathrm{Si}, \mathrm{Ca}, \mathrm{Al}, \mathrm{K}$ dan $\mathrm{Fe}$ dalam adsorpsi ion $\mathrm{Cd}(\mathrm{II})$ dan $\mathrm{Zn}$ (II) juga dapat dilihat dari terjadinya penurunan kadar $\mathrm{Zn}(\mathrm{II})$ pada LLA-ICR setelah proses adsorpsi $\mathrm{Cd}(\mathrm{II})$ dan peningkatannya setelah proses adsorpsi $\mathrm{Zn}(\mathrm{II})$. Begitu juga dengan terdeteksinya ion $\mathrm{Cd}(\mathrm{II})$ setelah proses adsorpsi, baik dalam bentuk unsur tunggal dan oksidanya (Tabel 1). Pada sludge IPAL domestik juga didapatkan dalam bentuk oksida $\mathrm{SiO}_{2}, \mathrm{Al}_{2} \mathrm{O}_{3}, \mathrm{Fe}_{2} \mathrm{O}_{3}$ dan $\mathrm{CaO}$ berturut-turut $46,0 \%, 12,6 \%, 14,8 \%$ dan 13,8\% (Nielsen et al., 2015). 
Keberadaan dan peran unsur-unsur $\mathrm{Si}, \mathrm{Ca}, \mathrm{Al}$, dan $\mathrm{C}$ dalam proses adsorpsi $\mathrm{Cd}(\mathrm{II})$ dan $\mathrm{Zn}(\mathrm{II})$ juga didukung oleh hasil analisis karakterisasi dengan EDX (Tabel 2). Hal ini dapat dilihat dari terjadinya penurunan kadar semua unsur setelah proses adsorpsi Cd(II) dan $\mathrm{Zn}$ (II), terdeteksinya $\mathrm{Cd}(\mathrm{II})$ setelah proses adsorpsi $\mathrm{Cd}(\mathrm{II})$ dan terdeteksinya $\mathrm{Zn}$ (II) setelah proses adsorpsi $\mathrm{Zn}(\mathrm{II})$.

Tabel 2

Analisis EDX kadar unsur adsorben LLA-ICR sebelum dan sesudah proses adsorpsi ion Cd(II) dan $\mathrm{Zn}(\mathrm{II})$

\begin{tabular}{llll}
\hline $\begin{array}{l}\text { Elemen } \\
\text { Adsobelum } \\
\text { Adsi (\%) }\end{array}$ & $\begin{array}{l}\text { Sesudah Adsorpsi } \\
\text { Cd(II) (\%) }\end{array}$ & $\begin{array}{l}\text { Sesudah Adsorpsi } \\
\text { Zn(II) (\%) }\end{array}$ \\
\hline $\mathrm{C}$ & 43,46 & 14,12 & 24,57 \\
$\mathrm{O}$ & 43,16 & 18,51 & 37,27 \\
$\mathrm{Al}$ & 3,67 & 1,55 & 1,02 \\
$\mathrm{Si}$ & 5,55 & 2,68 & 1,47 \\
$\mathrm{Ca}$ & 3,33 & 0 & 1,42 \\
$\mathrm{~K}$ & 0,83 & 0,11 & 0 \\
$\mathrm{Cd}$ & 0 & 63,03 & 0 \\
$\mathrm{Zn}$ & 0 & 0 & 34,25 \\
\hline
\end{tabular}

Photo morfologi permukaan dan spektra SEM-EDX adsorben LLA-ICR sebelum dan sesudah proses adsorpsi Cd(II) dan Zn(II) disajikan pada Gambar 5 A dan B). Dari Gambar 5 (A1, A2 dan A3) terlihat mikrograf SEM dengan perbesaran 500 kali menunjukkan struktur permukaan dan porositas adsorben LLA-ICR sebelum dan sesudah proses adsorpsi Cd(II) dan Zn(II). Struktur permukaan adsorben sebelum proses adsorpsi (Gambar 5 (A1)) terlihat lebih kasar dan berpori jika dibandingkan dengan sesudah proses adsorpsi ion Cd(II) dan Zn(II) (Gambar 5 (A2) dan (A3)). Bagian tersebutlah yang diperkirakan bertanggung jawab untuk menjerap ion logam dan tempat terjadinya difusi intra pori selama proses adsorpsi (Abo-El-Enein et al., 2017). Kemungkinan mekanisme adsorpsi ion logam pada adsorben LLA-ICR adalah adsorpsi fisik dan kimia di permukaan situs aktif. Hal ini juga dibuktikan dengan hasil karakterisasi dengan spektroskopi dispersif energi X-Ray (EDX) (Gambar 5 B) di mana terlihat adanya Si, $\mathrm{Ca}, \mathrm{Al}, \mathrm{K}, \mathrm{O}$ dan $\mathrm{P}$ dan besi pada permukaan adsorben LLA-ICR sebelum proses adsorpsi (Gambar 5(BI)), sedangkan $\mathrm{Cd}$ (II) dan Zn(II) tidak terlihat. Namun ion $\mathrm{Cd}(\mathrm{II})$ terlihat setelah proses adsorpsi $\mathrm{Cd}(\mathrm{II})$, dan $\mathrm{Zn}$ (II) terlihat setelah proses adsorpsi Zn(II) (Gambar 5 (B2) dan (B3).

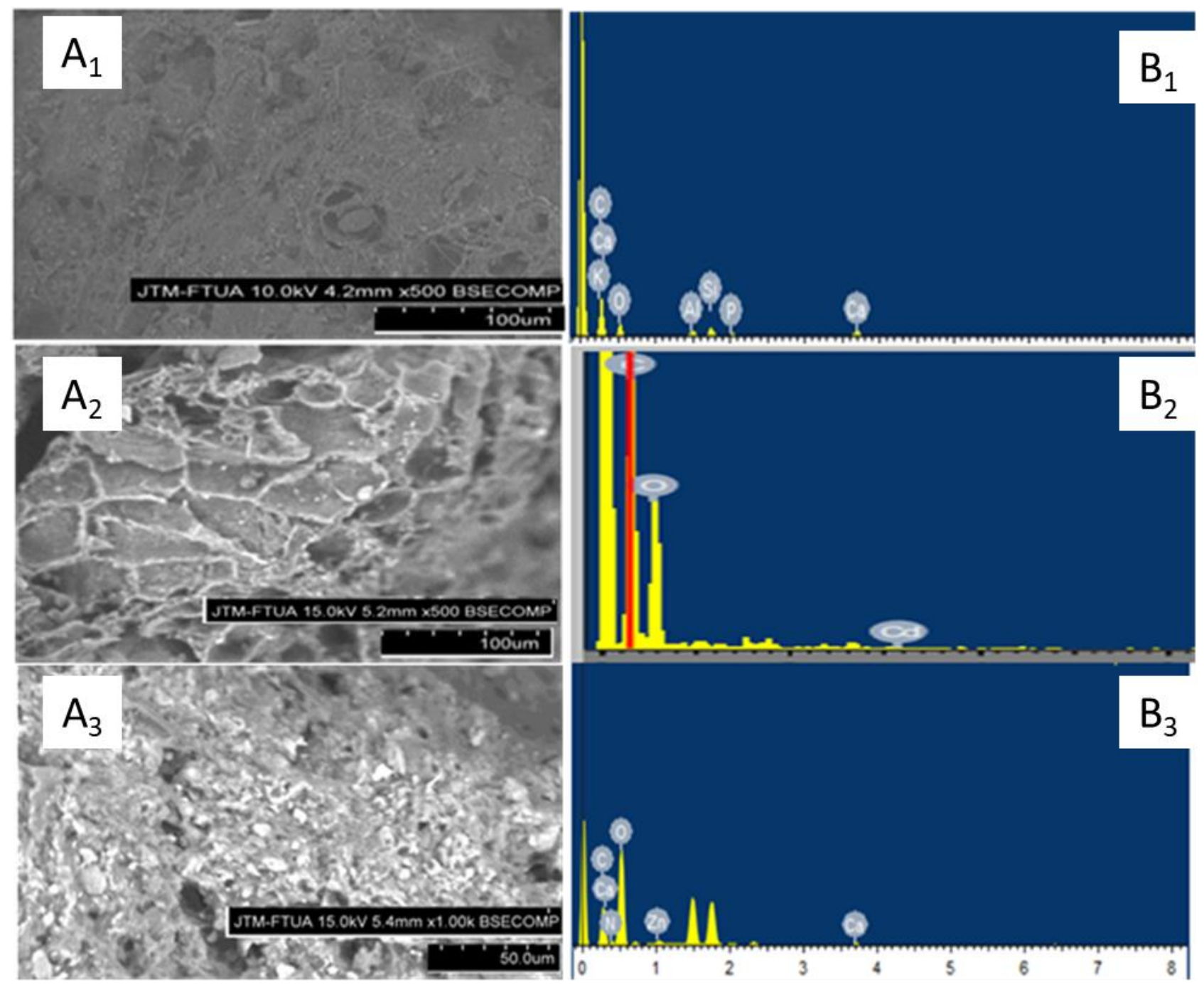

Gambar 5. Hasil analisis SEM-EDX, photo morfologi permukaan dan spektrum adsorben LLA-ICR sebelum 5(A1dan B1), sesudah proses adsorpsi Cd(II) (5 A2 dan B2) dan sesudah proses adsorpsi Zn(II) (5 A3 dan B3) 


\subsection{Perbandingan kapasitas adsorpsi Cd(II) dan $\mathrm{Zn}$ (II) dengan beberapa adsorben dari berbagai jenis lumpur}

Perbandingan kapasitas adsorpsi Cd(II) dan $\mathrm{Zn}(\mathrm{II})$ dengan beberapa adsorben dari berbagai jenis lumpur dengan perlakuan $\mathrm{pH}$ larutan dan dosis adsorben dalam literatur disajikan pada Tabel 3. Terlihat bahwa penyerapan optimum ion $\mathrm{Cd}(\mathrm{II})$ dan $\mathrm{Zn}(\mathrm{II})$ oleh adsorben dari beberapa jenis lumpur terjadi pada $\mathrm{pH} 5$ dengan dosis dari $0,02 \mathrm{~g}-7,5 \mathrm{~g}$. Kapasitas adsorpsi ion $\mathrm{Cd}(\mathrm{II})$ dan $\mathrm{Zn}$ (II) terlihat mempunyai rentang yang luas yaitu dari $1,3 \mathrm{mg} / \mathrm{g}-195,7 \mathrm{mg} / \mathrm{g}$, namun pada umumnya kapasitas adsorpsinya di bawah $53 \mathrm{mg} / \mathrm{g}$, termasuk adsorben LLA-ICR. Kapasitas adsorpsi oleh adsorben LLA-ICR didapatkan 3,7-29,8 $\mathrm{mg} / \mathrm{g}$ untuk ion $\mathrm{Cd}(\mathrm{II})$ dan 1,7-10,3 untuk ion $\mathrm{Zn}(\mathrm{II})$.

Tabel 3. Perbandingan kapasitas penyerapan beberapa adsorben dari berbagai jenis lumpur

\begin{tabular}{llllll}
\hline $\begin{array}{l}\text { Adsorben } \\
\text { (Jenis Lumpur) }\end{array}$ & Adsorbat & $\mathbf{p H}$ & $\begin{array}{l}\text { Dosis } \\
\text { (g) }\end{array}$ & $\begin{array}{l}\text { Kapasitas } \\
\text { Adsorpsi/Qe (mg/g) }\end{array}$ & Pustaka \\
\hline Industri susu & $\mathrm{Cd}(\mathrm{II})$ & 5 & $0,2-0,5$ & $1,3-1,7$ & $\begin{array}{l}31,2-565,1 \\
8,6-195,7\end{array}$ \\
IPAL komunal & $\mathrm{Cd}(\mathrm{II})$ & & & 0,02 & (Liu et al., 2015) \\
$\begin{array}{l}\text { Industri proses produksi } \\
\text { plastik dan pupuk }\end{array}$ & $\mathrm{Zn}(\mathrm{II})$ & 4,5 & 0,3 & 5,5 & (Velghe et al., 2012) \\
Pabrik baja & & 5 & & & (Bhattacharya et al., 2006) \\
Industri & $\mathrm{Zn}(\mathrm{II})$ & 5 & 5 & 15,53 & (Gutiérrez-Segura et al., 2012) \\
Ipal komunal & $\mathrm{Cd}(\mathrm{II})$ & 6,5 & 0,5 & 16,7 & (Phuengprasop et al., 2011) \\
IPAL komunal & $\mathrm{Cd}$ & 5 & 1,5 & 14,7 & (Siswoyo et al., 2014) \\
Elektroplating & $\mathrm{Cd}(\mathrm{II})$ & 5 & $1,2-2,4$ & $5,3-9,2$ & (Bhatnagar and Minocha, 2009) \\
Pabrik baja & $\mathrm{Cd}(\mathrm{II})$ & $6,5-75$ & 0,1 & 41,2 & (Naiya et al., 2008) \\
Industri Crumb Rubber & $\mathrm{Cd}(\mathrm{II})$ & 5 & 7,5 & 36,23 & Pada penelitian ini \\
\hline
\end{tabular}

\section{Kesimpulan}

Dari hasil penelitian yang telah dilakukan dapat disimpulkan bahwa perlakuan $\mathrm{pH}$ dan dosis berpengaruh pada kapasitas penyerapan dan efisiensi penyerapan ion Cd(II) dan Zn(II) oleh adsorben LLA-ICR. Didapatkan bahwa semakin tinggi $\mathrm{pH}$ semakin tinggi kapasitas adsorpsi dan efisiensi penyisihan sampai mencapai $\mathrm{pH}$ optimum pada $\mathrm{pH}$ 5. Semakin rendah dosis adsorben, maka semakin tinggi kapasitas adsorpsi namun semakin rendah efisiensi penyisihan ion $\mathrm{Cd}(\mathrm{II})$ dan $\mathrm{Zn}$ (II). Didapatkan dosis adsorben optimum pada $0,1 \mathrm{~g}$ dengan kapasitas adsorpsi dan efisiensi penyisihan ion $\mathrm{Cd}(\mathrm{II})$ lebih besar dari $\mathrm{Zn}(\mathrm{II})$. Kapasitas penyerapan maksimum untuk ion Cd(II) didapatkan $29,8 \mathrm{mg} / \mathrm{g}$ dan $10,3 \mathrm{mg} / \mathrm{g}$ untuk ion $\mathrm{Zn}(\mathrm{II})$. Efisiensi penyerapan maksimum intuk ion $\mathrm{Cd}(\mathrm{II})$ didapatkan $95,4 \%$ dan $87,9 \%$ untuk ion $\mathrm{Zn}(\mathrm{II})$

\section{Ucapan terima kasih}

Penulis mengucapkan terimakasih kepada Pusdiklat Kementerian Perindustrian yang telah memberi dana penelitian ini dan Kepala Baristand Industri Padang yang telah memberi izin penggunaan fasilitas laboratorium untuk penelitian dan pengujian.

\section{Daftar pustaka}

Abo-El-Enein, S.A., Shebl, A., Abo El-Dahab, S.A., 2017. Drinking water treatment sludge as an efficient adsorbent for heavy metals removal. Appl. Clay Sci. 146, 343-349. doi:10.1016/j.clay.2017.06.027

Artola, a, Martin, M., Balaguer, M., Rigola, M., 2000. Isotherm model analysis for the adsorption of Cd (II), $\mathrm{Cu}$ (II), Ni (II), and Zn (II) on anaerobically digested sludge. J. Colloid Interface Sci. 232, 64-70. doi:10.1006/jcis.2000.7186

Bhatnagar, A., Minocha, A.K., 2009. Utilization of industrial waste for cadmium removal from water and immobilization in cement. Chem. Eng. J. 150, 145-151. doi:10.1016/j.cej.2008.12.013

Bhattacharya, A.K., Mandal, S.N., Das, S.K., 2006. Adsorption of $\mathrm{Zn}$ (II) from aqueous solution by using different adsorbents. Chem. Eng. J. 123, 43-51.

Brady, J.M., Tobin, J.M., 1995. Binding of hard and soft metal ions to Rhizopus arrhizus biomass. Enzyme Microb. Technol. 17, 791-796. doi:10.1016/01410229(95)00142-R

Cheng, F., Luo, H., Hu, L., Yu, B., Luo, Z., Fidalgo De Cortalezzi, M., 2016. Sludge carbonization and activation: From hazardous waste to functional materials for water treatment. J. Environ. Chem. Eng. 4, 4574-4586. doi:10.1016/j.jece.2016.11.013

Ding, R., Zhang, P., Seredych, M., Bandosz, T.J., 2012. Removal of antibiotics from water using sewage sludge- and waste oil sludge-derived adsorbents. Water Res. 46, 4081-4090. doi:10.1016/ j.watres.2012.05.013

Farhan, A.M., Al-Dujaili, A.H., Awwad, A.M., 2013. Equilibrium and kinetic studies of cadmium(II) and lead(II) ions biosorption onto Ficus carcia leaves. Int. J. Ind. Chem. 4, 1-8. doi:10.1186/2228-5547-4-24

Freitas, O.M.M., Martins, R.J.E., Delerue-Matos, C.M., Boaventura, R.A.R., 2008. Removal of Cd(II), Zn(II) and $\mathrm{Pb}$ (II) from aqueous solutions by brown marine macro algae: Kinetic modelling. J. Hazard. Mater. 153, 493-501.

Fu, F., Wang, Q., 2011. Removal of heavy metal ions from wastewaters: A review. J. Environ. Manage. 92, 407-418. doi:10.1016/j.jenvman.2010.11.011

Gómez-Pacheco, C. V., Rivera-Utrilla, J., Sánchez-Polo, M., López-Peñalver, J.J., 2012. Optimization of the preparation process of biological sludge adsorbents 
for application in water treatment. J. Hazard. Mater. 217-218, 76-84. doi:10.1016/j.jhazmat.2012.02.067

González, P.G., Pliego-Cuervo, Y.B., 2014. Adsorption of $\mathrm{Cd}(\mathrm{II}), \mathrm{Hg}(\mathrm{II})$ and $\mathrm{Zn}$ (II) from aqueous solution using mesoporous activated carbon produced from Bambusa vulgaris striata. Chem. Eng. Res. Des. 92, 1-10. doi:10.1016/j.cherd.2014.02.013

Gupta, N., Amritphale, S.S., Chandra, N., 2010. Removal of Zn (II) from aqueous solution by using hybrid precursor of silicon and carbon. Bioresour. Technol. 101, 3355-3362.

Gutiérrez-Segura, E., Solache-Ríos, M., Colín-Cruz, A., Fall, C., 2012. Adsorption of cadmium by $\mathrm{Na}$ and $\mathrm{Fe}$ modified zeolitic tuffs and carbonaceous material from pyrolyzed sewage sludge. J. Environ. Manage. 97, 6-13. doi:10.1016/j.jenvman.2011.11.010

Hadi, P., Xu, M., Ning, C., Sze Ki Lin, C., McKay, G., 2015. A critical review on preparation, characterization and utilization of sludge-derived activated carbons for wastewater treatment. Chem. Eng. J. doi:10.1016/j.cej.2014.08.088

Harmiwati, Salmariza, S., Kurniawati, D., Lestari, I., Chaidir, Z., Desmiarti, R., Zein, R., 2017. Biosorption of $\mathrm{Pb}$ (II) And $\mathrm{Zn}$ (II) metal ions from aqueous solutions by stem tree of soybean using continuous. ARPN J. Eng. Appl. Sci. 12, 5258-5262.

Hunsom, M., Autthanit, C., 2013. Adsorptive purification of crude glycerol by sewage sludgederived activated carbon prepared by chemical activation with $\mathrm{H} 3 \mathrm{PO} 4, \mathrm{~K} 2 \mathrm{CO} 3$ and $\mathrm{KOH}$. Chem. Eng. J. 229, 334-343.

Ihsanullah, Al-Khaldi, F.A., Abusharkh, B., Khaled, M., Atieh, M.A., Nasser, M.S., Laoui, T., Saleh, T.A., Agarwal, S., Tyagi, I., Gupta, V.K., 2015. Adsorptive removal of cadmium(II) ions from liquid phase using acid modified carbon-based adsorbents. J. Mol. Liq. 204, 255-263. doi:10.1016/j.molliq.2015.01.033

Khosravan, A., Lashkari, B., 2011. Adsorption of Cd(II) by Dried Activated Sludge A. Iran. J. Chem. Eng. 8, 41-56.

Lestari, I., Sy, S., Kurniawati, D., Alif, A., Zein, R., Aziz, H., 2016. Effect of $\mathrm{pH}$ on the biosorption of heavy metal by alginate immobilized durian (Durio zibethinus) seed. Der Pharma Chem. 8, 294-300.

Li, M., Li, M., Feng, C., Zeng, Q., 2014. Preparation and characterization of multi-carboxyl-functionalized silica gel for removal of $\mathrm{Cu}$ (II), Cd (II), Ni (II) and $\mathrm{Zn}(\mathrm{II})$ from aqueous solution. Appl. Surf. Sci. 314, 1063-1069. doi:10.1016/j.apsusc.2014.06.038

Liu, W., Zhang, J., Jin, Y., Zhao, X., Cai, Z., 2015. Adsorption of $\mathrm{Pb}(\mathrm{II}), \mathrm{Cd}(\mathrm{II})$ and $\mathrm{Zn}$ (II) by extracellular polymeric substances extracted from aerobic granular sludge: Efficiency of protein. J. Environ. Chem. Eng. 3, 1223-1232. doi:10.1016/ j.jece.2015.04.009

Monier, M., Abdel-Latif, D.A., 2012. Preparation of cross-linked magnetic chitosan-phenylthiourea resin for adsorption of $\mathrm{Hg}(\mathrm{II}), \mathrm{Cd}(\mathrm{II})$ and $\mathrm{Zn}$ (II) ions from aqueous solutions. J. Hazard. Mater. 209-210, 2409. doi:10.1016/j.jhazmat.2012.01.015

Monsalvo, V.M., Mohedano, A.F., Rodriguez, J.J., 2011. Activated carbons from sewage sludge. Application to aqueous-phase adsorption of 4-chlorophenol.
Desalination 277, 377-382. doi:10.1016/j.desal. 2011.04.059

Naiya, T.K., Bhattacharya, A.K., Das, S.K., 2008. Removal of $\mathrm{Cd}(\mathrm{II})$ from aqueous solutions using clarified sludge. J. Colloid Interface Sci. 325, 48-56. doi:10.1016/j.jcis.2008.06.003

Nielsen, L., Zhang, P., Bandosz, T.J., 2015. Adsorption of carbamazepine on sludge/fish waste derived adsorbents: Effect of surface chemistry and texture. Chem. Eng. J. 267, 170-181. doi:10.1016/j.cej. 2014.12.113

Phuengprasop, T., Sittiwong, J., Unob, F., 2011. Removal of heavy metal ions by iron oxide coated sewage sludge. J. Hazard. Mater. 186, 502-507. doi:10.1016/j.jhazmat.2010.11.065

Rao, R.A.K., Kashifuddin, M., 2016. Adsorption studies of $\mathrm{Cd}(\mathrm{II})$ on ball clay: Comparison with other natural clays. Arab. J. Chem. 9, S1233-S1241. doi:10.1016/ j.arabjc.2012.01.010

Salmariza, S., 2012. Pemanfaatan limbah lumpur proses activated sludge industri karet remah sebagai adsorben. J. Ris. Ind. VI, 175-182.

Salmariza, S., Mawardi, M., Hariyani, R., Kasman, M., 2014. Pengembangan adsorben dari limbah lumpur industri crumb rubber yang diaktivasi dengan $\mathrm{H} 3 \mathrm{PO} 4$ untuk menyerap ion Cr(VI). J. Litbang Ind. 4, 67-77. doi:10.24960/jli.v4i2.647.67-77

Samolada, M.C., Zabaniotou, A.A., 2014. Comparative assessment of municipal sewage sludge incineration, gasification and pyrolysis for a sustainable sludge-toenergy management in Greece. Waste Manag. doi:10.1016/j.wasman.2013.11.003

Sharma, A., Lee, B.K., 2014. Cd(II) removal and recovery enhancement by using acrylamide-titanium nanocomposite as an adsorbent. Appl. Surf. Sci. 313, 624-632. doi:10.1016/j.apsusc.2014.06.034

Siswoyo, E., Mihara, Y., Tanaka, S., 2014. Determination of key components and adsorption capacity of a low cost adsorbent based on sludge of drinking water treatment plant to adsorb cadmium ion in water. Appl. Clay Sci. 97-98, 146-152. doi:10.1016/j.clay.2014.05.024

Smith, K.M., Fowler, G.D., Pullket, S., Graham, N.J.D., 2009. Sewage sludge-based adsorbents: A review of their production, properties and use in water treatment applications. Water Res. 43, 2569-2594.

Spellman, F., 2014. Handbook of water and wastewater treatment plant operations, third. ed. CRC Press, New York.

Sy, S., Harmiwati, Kurniawati, D., Aziz, H., Chaidir, Z., Zein, R., 2018. Removal of Zinc onto several adsorbents derived from waste activated sludge of crumb rubber industry (CRI-WAS). Int. J. Adv. Sci. Eng. Inf. Technol. 8, 157-164. doi:10.18517/ ijaseit.8.1.4084

Sy, S., Lestari, I., Kurniawati, D., Aziz, H., Chaidir, Z., Zein, R., 2016. Characterization of waste activated sludge of crumb rubber industry (CRI-WAS) as Adsorbent of Cd(II). Der Pharma Chem. 8, 228-235.

Velghe, I., Carleer, R., Yperman, J., Schreurs, S., D'Haen, J., 2012. Characterisation of adsorbents prepared by pyrolysis of sludge and sludge/disposal filter cake mix. Water Res. 46, 2783-2794. 
doi:10.1016/j.watres.2012.02.034

Wu, C., Song, M., Jin, B., Wu, Y., Huang, Y., 2013. Effect of biomass addition on the surface and adsorption characterization of carbon-based adsorbents from sewage sludge. J. Environ. Sci. (China) 25, 405-412. doi:10.1016/S10010742(12)60028-X

Yang, C., Wang, J., Lei, M., Xie, G., Zeng, G., Luo, S.,
2010. Biosorption of zinc(II) from aqueous solution by dried activated sludge. J. Environ. Sci. 22, 675680. doi:10.1016/S1001-0742(09)60162-5

Zaini, M.A.A., Zakaria, M., Mohd.-Setapar, S.H., CheYunus, M.A., 2013. Sludge-adsorbents from palm oil mill effluent for methylene blue removal. J. Environ. Chem. Eng. 1, 1091-1098. doi:10.1016/j.jece. 2013.08.026 